This is an Open Access article distributed under the terms of the Creative Commons Attribution 4.0 International License which permits unrestricted non-commercial use, distribution, and reproduction in any medium, provided the original work is properly cited.

\title{
THE INFLUENCE OF CONTINUITY OF CARE (COC) TO THE INCREASING OF COGNITIVE, AFFECTIVE AND PSYCHOMOTOR ASPECTS OF MIDWIFERY CARE TO STUDENTS OF MIDWIFERY STUDY PROGRAM
}

\section{LASIYATI YUSWO YANI ${ }^{1}$, ARIU DEWI YANTI ${ }^{2}$}

Bina Sehat PPNI health science institute Mojokerto regency East Java Indonesia

\section{Email : yuswoyani@gmail.com}

\section{ABSTRACT}

Keywords

Education should be able to form graduate competencies in accordance with community needs. The quality of midwives in Indonesia is still low, this is indicated by the passing of the competency test which tends to be volatile (RistekDikti, 2016). During this time the learning aspects are given fragmented and separate. Learning models are needed in accordance with the needs of the community, integrating all aspects related to community values and are dynamic according to the needs of the community. The purpose of this study was to find the effect of $\mathrm{CoC}$ learning methods on improving cognitive, affective and psychomotor midwifery students.

Learning, CoC, Cognitive, Affective, This study used "quasi-experimental non-equivalent pre-post test randomized intervention studies". Each student was assessed on affective, cognitive, and psychomotor aspects in the implementation of midwifery care in the 5th semester before and after the implementation of $\mathrm{CoC}$, Each midwifery student carries out $\mathrm{CoC}$ care for a participant.

The results of the multivariate analysis using the Wilks' Lambda test showed that the greatest effect of time effect on affective variables was shown by the results of Partial Eta Squared 0.982, meaning that time could explain 98.2\% of the variance in the multivariate value. It means that this learning method is proven to improve student learning experiences. 


\section{INTRODUCTION}

Comprehensive services, integrating knowledge, clinical skills with interpersonal skills, cultural responsiveness, sensitivity to their values and responsive to community needs (Renfrew et al., 2014). Women need midwives who are not only able to solve midwifery problems, but are also able to be good listeners, can communicate well, be patient and friendly in completing midwifery management (Filby, Mcconville, \& Portela, 2016).

Community needs in midwifery care constitute an integral whole which is inseparable from one another and is not fragmented between midwifery care, fiological, psychological, religious, sociocultural, and other values contained within it. (Ten Hoope-Bender et al., 2014).

Education should be able to form graduate competencies in accordance with community needs. The quality of midwives in Indonesia is still low, this is indicated by the passing of the competency test which tends to be volatile (RistekDikti, 2016). During this time the learning aspects are given fragmented and separate. Learning models are needed in accordance with the needs of the community, integrating all aspects related to community values and are dynamic according to the needs of the community.

Continuity of Care (CoC) in midwifery services it is highly recommended and recommended by many developed and developing countries in the world (Forster et al., 2016b). The concept of "Women centered care" is at the core of midwifery practice and underlies the philosophical statement of the International Confederation of Midwives and Australian College of Midwives (Yanti, Claramita, Emilia, \& Hakimi, 2015). The basic principle "women centered" ensures the focus on pregnancy and birth as the beginning of family life, not only as a stage of life that must be protected. These phases of life take into account the full meaning and value of each woman (Bowers, Cheyne, Mould, \& Page, 2015).

Women's-centered care in clinical settings is safe, supportive and gentle. This is the philosophical foundation of midwifery education, which in turn promotes the understanding needed by midwifery students to treat women holistically.

$\mathrm{CoC}$ by midwifery students in question is a related experience between students and clients in midwifery services. This starts from the initial contact during pregnancy until the period after delivery and obtains family planning services. Important activities for students to improve students' abilities and understanding of the philosophy of midwifery care with holistic and integrated. This method of midwifery care provides an opportunity for midwives and midwife students to be able to explore and understand pregnancy, childbirth, and the period after childbirth. This care also ensures that women and their babies get the 
best and sustainable care throughout the cycle of pregnancy, childbirth and afterwards. This method of learning with $\mathrm{CoC}$ has advantages, namely the concept of patient-based learning with patients as teaching material. Students are directly related and actively involved with actual patients complete with other health care providers. These two things then have an impact on the constructivity of student understanding of the philosophy of femalecentered midwifery care. Such midwifery learning methods have been developed in midwifery academy education in Australia as well as other developed countries. This study explores the experiences of midwifery students in providing care with $\mathrm{CoC}$ to patients. It is expected that with the learning method that directly applies in the field, students will be able to integrate midwifery science and theory with participants who are given care. Thus participants will get midwifery care from students according to the needs of participants. This continuous care if successful will minimize unneeded midwifery actions and delay the emergency referral of maternal and neonatal emergency. In addition to the care given, it will affect the understanding of midwives' students about holistic and integrated care, for participants to be more satisfied with $\mathrm{CoC}$ care because the period of pregnancy, childbirth, postpartum and afterwards receive continuous monitoring with a humanist approach.

\section{MATERIALS AND METHODS}

This study used a "quasi-experimental nonequivalent pre-post test design randomized intervention studies" design. Each student was assessed on affective, cognitive, and psychomotor aspects in the implementation of midwifery care in the 5 th semester before and after the implementation of $\mathrm{CoC}$,Each midwifery student carries out $\mathrm{CoC}$ care for a participant. $\mathrm{CoC}$ is ongoing care for participants starting in the third trimester of pregnancy, childbirth, postpartum, neonates as well as postpartum family planning.

The research subjects were 58 students in the 5th semester of the Midwifery Diploma III study program who carried out a comprehensive final project.

Data obtained from data collection were carried out multifariate analysis tests using SPSS 21.

\section{RESULTS}

Descriptive analysis 


\begin{tabular}{|c|c|c|c|c|}
\hline Variable & $\begin{array}{l}\text { Mini } \\
\text { mum }\end{array}$ & $\begin{array}{l}\text { Maxi } \\
\text { mum }\end{array}$ & $\begin{array}{c}\mathrm{M} \\
\mathrm{ea} \\
\mathrm{n}\end{array}$ & $\begin{array}{l}\text { Stan } \\
\text { dard } \\
\text { Devi } \\
\text { ation }\end{array}$ \\
\hline \multicolumn{5}{|l|}{ Cognitive } \\
\hline $\begin{array}{ll}\text { a. } & \text { Pre } \\
& \text { exp } \\
& \text { eri } \\
& \text { me } \\
& \text { nt }\end{array}$ & 12. & 27 & $\begin{array}{l}19 \\
37\end{array}$ & $\begin{array}{c}4,1 \\
5\end{array}$ \\
\hline $\begin{array}{ll}\text { b. } & \text { Co } \\
\text { gni } \\
\text { tiv } \\
\text { e } 1 \\
\end{array}$ & 22 & 39 & $\begin{array}{c}29 \\
49\end{array}$ & $\begin{array}{c}4,0 \\
9\end{array}$ \\
\hline $\begin{array}{ll}\text { c. } & \text { Co } \\
\text { gni } \\
\text { tiv } \\
\text { e } 2\end{array}$ & 33 & 45 & $\begin{array}{l}40 \\
88\end{array}$ & $\begin{array}{c}2,3 \\
6\end{array}$ \\
\hline \multicolumn{5}{|l|}{ Affective } \\
\hline $\begin{array}{ll}\text { a. } & \text { Pre } \\
& \text { exp } \\
\text { eri } \\
\text { me } \\
\text { nt }\end{array}$ & 22 & 46 & $\begin{array}{l}35 \\
47\end{array}$ & $\begin{array}{c}5,4 \\
3\end{array}$ \\
\hline $\begin{array}{ll}\text { b. } & \text { Aff } \\
\text { ecti } \\
\text { ve } \\
1\end{array}$ & 43 & 69 & $\begin{array}{l}54, \\
03\end{array}$ & $\begin{array}{c}4,9 \\
0\end{array}$ \\
\hline $\begin{array}{ll}\text { c. } & \text { Aff } \\
\text { ecti } \\
\text { ve } \\
2\end{array}$ & 58 & 80 & $\begin{array}{l}72 \\
34\end{array}$ & $\begin{array}{c}4,5 \\
3\end{array}$ \\
\hline \multicolumn{5}{|l|}{$\begin{array}{l}\text { Psychomot } \\
\text { or }\end{array}$} \\
\hline $\begin{array}{ll}\text { a. } & \text { Pre } \\
& \text { exp } \\
\text { eri } \\
\text { me } \\
\text { nt }\end{array}$ & 9 & 21 & $\begin{array}{l}15, \\
10\end{array}$ & $\begin{array}{c}3,2 \\
5\end{array}$ \\
\hline $\begin{array}{ll}\text { b. } & \text { Psy } \\
\text { cho } \\
\text { mo } \\
\text { tor } \\
1\end{array}$ & 17 & 31 & 23 & $\begin{array}{c}3,3 \\
7\end{array}$ \\
\hline $\begin{array}{ll}\text { c. } & \text { Psy } \\
\text { cho } \\
\text { mo } \\
\text { tor } \\
2\end{array}$ & 25 & 35 & $\begin{array}{l}31, \\
61\end{array}$ & $\begin{array}{c}2,0 \\
1\end{array}$ \\
\hline
\end{tabular}

The results of the descriptive analysis showed an increase in minimum and maximum values on cognitive, affective and psychomotor variables. The biggest increase in the value of the affective variable and the lowest increase in the psychomotor variable. While the average value on cognitive, affective and psychomotor variables in the period of time, with the largest increase in the average value on affective variables and the lowest average value in psychomotor variables.

The results of the hypothesis test analysis

Multivariate test

\begin{tabular}{|c|c|c|c|c|}
\hline Variable & $\begin{array}{l}\text { Statis } \\
\text { tic } \\
\text { test }\end{array}$ & $\mathrm{F}$ & $\begin{array}{c}p \\
\text { val } \\
\text { ue }\end{array}$ & $\begin{array}{l}\text { Parti } \\
\text { al Eta } \\
\text { Squar } \\
\text { ed }\end{array}$ \\
\hline Aff & \multirow{3}{*}{$\begin{array}{l}\text { Wilks } \\
\text { Lamb } \\
d a\end{array}$} & $\begin{array}{c}1259, \\
28\end{array}$ & $\begin{array}{c}0,0 \\
00\end{array}$ & 0,978 \\
\hline $\begin{array}{l}\text { Cognitiv } \\
\mathrm{e}\end{array}$ & & $\begin{array}{l}1549, \\
27\end{array}$ & $\begin{array}{c}0,0 \\
00\end{array}$ & 0,982 \\
\hline $\begin{array}{l}\text { Psychom } \\
\text { otor }\end{array}$ & & $\begin{array}{l}1217, \\
66\end{array}$ & $\begin{array}{c}0,0 \\
00\end{array}$ & 0,977 \\
\hline
\end{tabular}

The results of the mlivariate analysis using the Wilks' Lambda test showed that the greatest effect of time effect on affective variables was shown by the results of Partial Eta Squared 0.982, meaning that time could explain $98.2 \%$ of the variance in the multivariate value. This means that this learning method is proven to improve student learning experiences.

Tests of Within-Subjects Effects

\begin{tabular}{|c|c|c|c|c|}
\hline Variable & & $\begin{array}{l}d \\
f\end{array}$ & $\begin{array}{c}\text { Mean } \\
\text { squar } \\
e\end{array}$ & $\begin{array}{c}p \\
\text { valu } \\
e\end{array}$ \\
\hline Affective & $\begin{array}{l}\text { Spheric } \\
\text { ity }\end{array}$ & 2 & $\begin{array}{c}6831 \\
5\end{array}$ & $\begin{array}{c}0,00 \\
0\end{array}$ \\
\hline
\end{tabular}




\begin{tabular}{lcccc}
\hline Cognitive & Assume & 2 & 20045 & 0,00 \\
& $d$ & & 3 & 0 \\
\cline { 3 - 5 } & & 2 & 4022, & 0,00 \\
Psychomono & & & 3 & 0 \\
tor & & &
\end{tabular}

The hypothesis test results using Sphericity Assumed showed that significantly the integrated learning model with the Continuity of care $(\mathrm{CoC})$ method had an effect on increasing the Affective aspect (Meansquare 6831.5> from $p$ value 0,000), the integrated learning model $\mathrm{CoC}$ significantly affected cognitive improvement for (Meansquare 20045.3> of $\mathrm{p}$ value 0,000), and the integrated $\mathrm{CoC}$ learning model significantly affected psychomotor improvement (Meansquare $4022.3>$ of $p$ value 0,000 )

\section{DISCUSSION}

Midwives have a very important function in independent care, collaboration and making appropriate referrals. Therefore midwives are required to be able to detect early signs and symptoms of pregnancy complications, provide obstetric and perinatal emergency assistance and refer cases (Fullerton, Severino, Brogan, \& Thompson, 2003).

Midwifery practices have expanded the role and function of focus on pregnant women, childbirth, childbirth, newborns, and toddlers shifting to efforts to anticipate the dynamic demands of the community, namely towards reproductive health services from conception to old age, including preconception counselling , labor, gynecological services, contraception, pre and post menopausal care, so this is a challenge for midwives (Forster et al., 2016a).

This study found that the integrated learning model of $\mathrm{CoC}$ significantly affected the improvement of cognitive, affective and psychomotor aspects of midwifery study students. This is because this learning method is suitable for midwife education, which requires more real skills than theory in the classroom.

This $\mathrm{CoC}$ learning model has advantages over other learning, especially the squad or conventional learning methods. This learning method requires students to be in a real community environment, besides that they will also carry out the teaching and learning process with real patient subjects (Gray, Taylor, \& Newton, 2016).

Evidenbased shows the usefulness of integrated and experimental clinical learning models in strengthening cognitive, psychomotor, and / or affective learning. Exposure to early patients in a genuine clinical environment provides students with important skills needed for professional practice in the future. Furthermore, integrated clinical education stimulates the transfer, application, and strengthening of classroom learning to authentic patient / client situations; provide exposure to various service delivery models; and promoting selfassessment and opportunities for skills development and professional growth (Hakim et al., 2014). 
The integrated clinical learning model with $\mathrm{CoC}$ allows Education management to control the type, sequence, and duration of clinical experience, as well as the qualifications of the medical practitioners involved. To maximize student readiness for patient / client demands in the twenty-first and more centuries, integrated clinical experience must be seen as an important component of the core curriculum in vocational education (Malau-Aduli et al., 2013).

The results show that the $\mathrm{CoC}$ clinical learning model increases students' understanding of the philosophy of midwifery care to a higher level than the fragmented care model. This finding shows that students using the $\mathrm{CoC}$ clinical learning model understand how to provide better obstetric care based on the obstetric care philosophy during practice. Learning through relational continuity of care is important to promote personal growth for midwifery students and therefore they are in a better position to offer holistic care. The continuity of care in relationships with women and holistic midwifery care practices seems to be more satisfying for students, and increases their confidence as midwives. Possibilities for this include more intensive and longer-term relationships between students and women during all phases of pregnancy, childbirth and postpartum, and / or increased understanding of midwifery philosophy in the practice of midwifery services.

Previous research has shown that students identify the importance of providing care and support in ways that are meaningful and focused on women from the beginning of pregnancy during the delivery period, and explain that this is a valuable learning experience.A study by Seibold reported that students experience personal transformation and assess their follow-up experience as valuable learning. The study found that providing this experience to all midwifery students enabled them to better understand all aspects of the midwifery care philosophy. Our study shows that the $\mathrm{CoC}$ clinical learning model provides opportunities for students to practice female-centered care. It is the presence of students and a focus on women who empower women in this case of learning.

In connection with changes after clinical experience, all students who applied the CoC learning model felt more competent and satisfied. It is shown that students develop their care skills and practices during the experience and consequently are satisfied with the practicum. The importance of clinical experience for the development of competencies and skills has been reported in the literature [22]; our research confirms the importance of clinical experience for students. 
It is interesting to note that competency and student satisfaction using the $\mathrm{CoC}$ learning model increased in this study. The results show that clinically following women during pregnancy, childbirth and postpartum allows students to get a suitable and satisfying learning experience. This study shows that there can be no doubt in adopting the $\mathrm{CoC}$ clinical learning model to enable midwifery students to develop relevant skills and competencies.

This research also confirms the elements of the midwifery care philosophy that contribute to the most positive learning experience for students. Consistent with other studies (Yani et al., 2015) . these elements are related to supporting students to get their learning, by being part of the midwifery care team, and thus feeling valued. This discovery strongly suggests the health aspects in which care agents foster not only the development of student beliefs and competencies, but also students' understanding of the philosophy of midwifery care. It is important that stakeholders in clinical education ensure that the clinical learning model not only recognizes this problem but also has a relevant structure to support learning. This should include providing a variety of experiences and recognizing students as honorable members of the health care team. There are many benefits associated with $\mathrm{CoC}$ learning models in $\mathrm{CoC}$ Learning midwifery care. The midwifery care model is based on the premise that pregnancy and birth are normal, woman-centered life. It is assumed that the basic philosophy of midwifery service is based on women's natural ability to experience births with minimal intervention or no routine intervention. The $\mathrm{CoC}$ care model offers a greater continuity of relationships by ensuring that women who give birth to children receive antenatal, intra and postnatal care from one midwife or practice partner. In our study, the $\mathrm{CoC}$ learning model offered to students provided additional benefits, such as early detection and rapid care for high-risk pregnancies. Of the 58 women who participated in this study, there were zero maternal deaths at the end of the implementation of the $\mathrm{CoC}$ learning model. Therefore, through the $\mathrm{CoC}$ care model implemented in the midwifery care system, this is in line with the target of the 4 \& 5 MDGs to reduce maternal and infant mortality.

\section{CONCLUSIONS}

The $\mathrm{CoC}$ learning model provides aunique learning opportunity for students to understand what the CoCas part of midwifery care philosophy offers to women. Be- ingaligned with women and developing effective relationships with the menable students to have a unique view of midwifery practice which instillsa strong philosophyof women-centredcare. The 
$\mathrm{CoC}$ learning model is proven to be able to improve student learning competencies in both the cognitive, avective and psychomotor aspects

\section{REFERENCES}

Bowers, J., Cheyne, H., Mould, G., \& Page, M. (2015). Continuity of care in community midwifery. Health Care Management Science, 18(2), 195-204. https://doi.org/10.1007/s10729-0149285-z

Filby, A., Mcconville, F., \& Portela, A. (2016). What Prevents Quality Midwifery Care? A Systematic Mapping of Barriers in Low and Middle Income Countries from the Provider Perspective, 1-20. https://doi.org/10.1371/journal.pone.0 153391

Forster, D. A., McLachlan, H. L., Davey, M.-A., Biro, M. A., Farrell, T., Gold, L., ... Waldenström, U. (2016a). Continuity of care by a primary midwife (caseload midwifery) increases women's satisfaction with antenatal, intrapartum and postpartum care: results from the COSMOS randomised controlled trial. $B M C$ Pregnancy and Childbirth, 16, 28. https://doi.org/10.1186/s12884-016- 0798-y

Forster, D. A., McLachlan, H. L., Davey, M. A., Biro, M. A., Farrell, T., Gold, L., ... Waldenström, U. (2016b). Continuity of care by a primary midwife (caseload midwifery) increases women's satisfaction with antenatal, intrapartum and postpartum care: Results from the COSMOS randomised controlled trial. $B M C$ Pregnancy and Childbirth, 16(1), 113. https://doi.org/10.1186/s12884016-0798-y

Fullerton, J., Severino, R., Brogan, K., \& Thompson, J. (2003). The International Confederation of Midwives' study of essential competencies of midwifery practice. Midwifery, 19(3), 174-190. https://doi.org/10.1016/S02666138(03)00032-9

Gray, J., Taylor, J., \& Newton, M. (2016). Embedding continuity of care experiences: An innovation in midwifery education. Midwifery, 33, 40-42.

Hakim, E. W., Moffat, M., Becker, E., Bell, K. A., Manal, T. J., Schmitt, L. A., \& Ciolek, C. (2014). Application of educational theory and evidence in support of an integrated model of clinical education. Journal of Physical Therapy Education, 28, 13-21.

Malau-Aduli, B. S., Lee, A. Y. S., Cooling, N., Catchpole, M., Jose, M., \& Turner, R. (2013). Retention of knowledge and 
perceived relevance of basic sciences in an integrated case-based learning (CBL) curriculum. BMC Medical Education, 13(1), 139.

Renfrew, M. J., McFadden, A., Bastos, M. H., Campbell, J., Channon, A. A., Cheung, N. F., ... McCormick, F. (2014). Midwifery and quality care: findings from a new evidenceinformed framework for maternal and newborn care. The Lancet, 384(9948), 1129-1145. https://doi.org/10.1016/ S0140-6736(14)60789-3

RistekDikti. (2016). Implementasi Uji Kompetensi Nasional bidang Kesehatan sebagai Langkah Konkrit Penjaminan Mutu Pendidikan Tinggi Kesehatan. Retrieved from https://www.ristekdikti.go.id/impleme ntasi-uji-kompetensi-nasional-bidangkesehatan-sebagai-langkah-konkritpenjaminan-mutu-pendidikan-tinggikesehatan/

Ten Hoope-Bender, P., De Bernis, L., Campbell, J., Downe, S., Fauveau, V., Fogstad, H., ... Van Lerberghe, W. (2014). Improvement of maternal and newborn health through midwifery. The Lancet. https://doi.org/10.1016/ S0140-6736(14)60930-2

Yani, L. Y., Nugraha, G. I., Wirakusumah, F. F., Husin, F., Abdulhak, I., Tarawan, V. M., \& Suwarsa, O. (2015). Peran Penerapan Model Pembelajaran Asuhan Persalinan Kala III dan IV
Terintegrasi Terhadap Motivasi dan Kompetensi Mahasiswa Serta Kepuasan Pasien Pada Praktik Klinik Kebidanan. Jurnal Pendidikan Dan Pelayanan Kebidanan Indonesia (Indonesian Journal of Education and Midwifery Care), 2(4), 17-24.

Yanti, Y., Claramita, M., Emilia, O., \& Hakimi, M. (2015). Students' understanding of "Women-Centred Care Philosophy" in midwifery care through Continuity of Care (CoC) learning model: A quasi-experimental study. BMC Nursing, 14(1), 1-7. https://doi.org/10.1186/s12912-0150072-z 